\title{
PERBANDINGAN METODE SMOTE RANDOM FOREST DAN SMOTE XGBOOST UNTUK KLASIFIKASI TINGKAT PENYAKIT HEPATITIS C PADA IMBALANCE CLASS DATA
}

\author{
Muhamad Syukron ${ }^{1}$, Rukun Santoso ${ }^{2}$, Tatik Widiharih ${ }^{3}$ \\ 1,2,3 Departemen Statistika FSM Universitas Diponegoro \\ rukunsantoso25@gmail.com
}

\begin{abstract}
Hepatitis causes around 1.4 million people die every year. This number makes hepatitis to be the largest contagious disease in the number of deaths after tuberculosis. Liver biopsy is still the best method for diagnosing the stage of hepatitis $\mathrm{C}$, but this method is an invasive, painful, expensive, and can cause complications. Non-invasively method needs to be developed, one of non-invasif method is machine learning. Random Forest and XGboost are classification methods that are often used, since they have many advantages over classical classification methods. The SMOTE algorithm can be used to improve the accuracy of predictions from imbalanced data. the data in this study have 24 independent variables in the form of patients self-data, hepatitis $\mathrm{C}$ symptoms, and laboratory test results. The dependent variable in this study is a binary category, namely the level of hepatitis $\mathrm{C}$ disease (fibrosis and cirrhosis). The results showed that the random forest and XGboost had an accuracy of around $74 \%$ but the recall value was less than 2\%. SMOTE random forest dan SMOTE XGboost have an accuracy \& recall value more than $75 \%$. SMOTE random forest has a higher accuracy for predicting fibrosis class while SMOTE XGboost is better in cirrhosis class. Variables that are more influental in determining hepatitis $\mathrm{C}$ stage are variables from laboratory test.
\end{abstract}

Keyword : Fibrosis, Cirrhosis, Random Forest, SMOTE, XGboost

\section{PENDAHULUAN}

Pada tahun 2019, terdapat 325 juta orang di dunia hidup dengan mengidap virus hepatitis $\mathrm{B}$ dan $\mathrm{C}$. Hepatitis $\mathrm{C}$ adalah penyakit hati yang disebabkan oleh virus hepatitis $\mathrm{C}(\mathrm{HCV})$. Virus hepatitis $\mathrm{C}$ adalah virus yang ditularkan melalui darah, misalnya dengan digunakannya peralatan kesehatan yang tidak aman, narkoba suntikan, tranfusi darah, serta praktik seksual yang mengarah pada paparan darah. Sebagian besar dari penderita yang terinfeksi hepatitis C kronis akan berkembang hingga menjadi sirosis atau kanker hati ${ }^{[9]}$.

Sejauh ini biopsi hati yang merupakan prosedur medis dengan cara mengambil sebagian kecil jaringan hati masih menjadi metode terbaik untuk mendiagnosis dan menentukan stadium fibrosis hati pada pasien dewasa dan anak-anak. Namun, cara ini merupakan proses invasif, menyakitkan, mahal, dan dapat menyebabkan komplikasi. Pengembangan metode selain biopsi hati yaitu metode non-invasif perlu ditingkatkan ${ }^{[1]}$. Penentuan tingkat penyakit hepatitis $\mathrm{C}$ bisa dilakukan berdasarkan dari hasil tes laboratorium rutin, penanda serum biokimia, dan berbagai teknik pencitraan terutama untuk mengukur kekakuan hati, atau kombinasi dari beberapa atau semua cara tersebut. Machine learning dapat diterapkan untuk menjaga keakuratan hasil prediksi berdasarkan data hasil rekam medis pasien. XGboost dan random forest merupakan metode klasifikasi yang bisa diterapkan untuk prediksi tingkat penyakit hepatitis $\mathrm{C}$ yaitu masuk ke tahap fibrosis atau sirosis. Kedua metode tersebut memiliki banyak keunggulan dibanding metode klasifikasi lainnya karena lebih robust terhadap outlier, waktu komputasi yang kecil, serta hasil yang akurat. 
Data yang dimiliki peneliti tidak selalu bisa diolah secara langsung, adakalanya data tersebut memiliki masalah seperti adanya imbalance class data. Dataset dikategorikan sebagai imbalance class data apabila proporsi antar kelas respon tidak ekuivalen ${ }^{[2]}$. Kelas respon tidak seimbang menyebabkan hasil prediksi akan akurat hanya pada satu kelas tertentu yaitu kelas dengan respon terbanyak. Penanganan imbalance class data bisa dilakukan dengan algoritma SMOTE yaitu membangkitkan data syntetic dari kelas minor.

\section{TINJAUAN PUSTAKA}

\subsection{Hepatitis C}

Hepatitis $\mathrm{C}$ merupakan penyakit yang dapat menyerang organ hati. Tahap hepatitis $\mathrm{C}$ diantaranya adalah inflamasi, fibrosis, sirosis, dan gagal hati atau kanker hati. Seseorang yang mengalami hepatitis $\mathrm{C}$ pada usia tua cenderung lebih susah untuk disembuhkan. Wanita secara biologis lebih mudah sembuh dengan sendirinya karena memiliki sistem imun lebih baik. Gejala yang mungkin dirasakan oleh seseorang yang mengidap penyakit hepatitis $C$ adalah rasa lelah, demam, diare, mual, dan bola mata atau kulitnya akan berwarna kekuningan ${ }^{[5]}$. Deteksi penyakit hepatitis $\mathrm{C}$ bisa dilakukan dengan mengambil sampel darah yaitu untuk melihat jumlah sel darah merah, sel darah putih, hemoglobin, dan trombosit. Selain itu perlu juga untuk melihat jumlah enzim aspartate aminotransferase (AST) dan alanaine aminotransferase (ALT) dalam darah. Meningkatnya enzim AST dan ALT bisa mengindikasikan adanya gangguan organ hati $^{[8]}$. Jumlah HCV RNA juga perlu diukur untuk melihat banyaknya virus hepatitis C dalam tubuh seseorang.

\subsection{Pre-Processing Data}

Data yang diambil dari lapangan tidak bisa digunakan secara langsung karena bisa saja data tersebut memiliki beberapa masalah yang perlu diselesaikan agar menjadi data yang bersih dari noise. Data yang tidak bersih artinya ada masalah seperti missing value (data hilang) serta adanya outlier. Keberadaan missing value bisa diatasi dengan menghilangkan observasi yang memiliki data hilang tersebut atau mengganti data dengan suatu estimasi nilai, misalkan dengan nilai modus apabila data berbentuk kategorik dan dengan nilai rata-rata apabila data memiliki nilai kontinyu ${ }^{[6]}$. Outlier bisa dideteksi dengan boxplot. Data dikategorikan sebagai outlier apabila berada diluar tubuh dan whisker boxplot yaitu nilainya lebih besar dari Q3+1,5*IQR atau kurang dari Q1+1,5*IQR. Q1 adalah kuartil bawah, Q3 adalah kuartil atas, serta IQR merupakan interquartile (Q3-Q1) ${ }^{[4]}$.

\subsection{Random Search \& Grid Search}

Random forest dan XGboost memiliki beberapa parameter yang perlu diatur agar menghasilkan kumpulan pohon keputusan yang dapat memprediksi tingkat penyakit hepatitis $\mathrm{C}$ secara akurat. Parameter terbaik bisa dicari dengan beberapa algoritma seperti random search dan grid search. Algoritma grid search akan mencobakan semua parameter yang ditentukan oleh peneliti sedangkan random search hanya akan mencoba beberapa kombinasi yang jumlah kombinasinya sudah ditentukan. Random search akan memiliki range percobaan yang lebih besar dibandingkan grid search jika jumlah percobaan yang ditentukan sama. Random search juga akan efektif digunakan apabila jumlah dimensi parameter yang dicobakan besar. 


\subsection{Holdout Validation \& K-Fold Validation}

Data yang ada biasanya tidak seluruhnya digunakan dalam proses pelatihan. Untuk menghindari overfitting maka model harus dibangun sedemikian rupa sehingga ketika ada data baru bisa diprediksi sama baiknya dengan menggunakan data pada proses pelatihan. Pengujian model bisa dilakukan dengan data test yang telah memiliki label kelas respon. Pembagian data train dan data test bisa dilakukan dengan holdout validation yaitu membagi data menjadi 2 bagian dengan proporsi tertentu yang ditentukan oleh peneliti. Proporsi yang biasa digunakan oleh peneliti adalah 60/40,70/30, atau 80/20 ${ }^{[7]}$. Selain holdout validation, data juga bisa dibagi menjadi data latih dan data uji dengan metode K-fold cross validation. Metode ini membagi data latih dan data uji sebanyak "k" kelompok, sehingga proses pelatihan akan menjadi sebanyak " $k$ " kemudian performance dari model merupakan rata-rata dari semua proses pelatihan tersebut.

\subsection{XGboost}

XGboost merupakan salah satu metode boosting yaitu kumpulan decission tree yang pembangungan pohon berikutnya akan bergantung pada pohon sebelumnya. Pohon pertama dalam XGboost akan lemah dalam melakukan klasifikasi dengan inisialisasi probability yang ditentukan oleh peneliti dan kemudian akan dilakukan update bobot pada setiap pohon yang dibangun sehingga menghasilkan kumpulan pohon klasifikasi yang kuat. Prediksi dilakukan dengan menjumlahkan seluruh bobot yang ada di setiap pohon dan kemudian memasukkan nilai tesebut ke fungsi logistik. XGboost akan meminimumkan fungsi objektif sebagai berikut:

$$
L^{(t)}=\sum_{i=1}^{n} l\left(y_{i}, \hat{y}_{i}^{(t-1)}+f_{t}\left(x_{i}\right)\right)+\Omega\left(f_{t}\right)
$$

Loss function pada klasifikasi kelas respon biner bisa menggunakan log loss. Persamaan Omega merupakan parameter regularisasi yang akan membuat model berusaha menghindari overfitting. Nilai gain bisa ditentukan untuk penentuan splitting node. Berikut ini adalah rumus untuk mencari nilai gain pada XGboost:

$$
L_{\text {split }}=\frac{1}{2}\left[\frac{\left(\sum_{i \in I_{L}} g_{i}\right)^{2}}{\sum_{i \in I_{L}} h_{i}+\lambda}+\frac{\left(\sum_{i \in I_{R}} g_{i}\right)^{2}}{\sum_{i \in I_{L}} h_{R}+\lambda}-\frac{\left(\sum_{i \in I} g_{i}\right)^{2}}{\sum_{i \in I} h_{i}+\lambda}\right]-\gamma
$$

Nilai $g_{i}$ dan $h_{i}$ merupakan turunan pertama dan kedua loss function pada XGboost ${ }^{[3]}$.

\subsection{Random Forest}

Random Forest (RF) adalah metode klasifikasi dan regresi yang berbentuk kumpulan pohon keputusan. Dalam model Random Forest, masing-masing pohon adalah Classification and Regression Trees (CART) yang menggunakan Decrease Gini Impurity dalam pemilihan prediktor pemisah dari subset yang dipilih secara acak dari semua variabel prediktor yang tersedia. Setiap pohon juga tidak menggunakan semua data asli melainkan menggunakan data sampel bootstrap dengan pengembalian. Penentuan kelas diambil berdasarkan mayoritas hasil vote dari semua pohon yang terbentuk. Beberapa parameter random forest adalah mtry yaitu jumlah feature yang dicobakan dalam proses pemilahan serta ntree yang merupakan jumlah pohon yang dibangun dalam suatu model. 


\subsection{SMOTE}

Metode SMOTE menggunakan prinsip oversampling yaitu menambah data dari kelas minor agar jumlahnya seimbang dengan data dari kelas mayor. SMOTE akan membangkitkan data dari kelas minor dengan pendekatan ketetanggan ${ }^{[2]}$. Misalkan diberikan data dengan jumlah variabel $\mathrm{p}$ maka jarak antara $x^{T}=\left[x_{1}, x_{2}, \ldots, x_{p}\right]$ dan $z^{T}=\left[z_{1}, z_{2}, \ldots, z_{p}\right]$ adalah $d(x, y)=$ $\sqrt{\left(x_{1}-z_{1}\right)^{2}+\left(x_{2}-z_{2}\right)^{2}+\cdots+\left(x_{p}-z_{p}\right)^{2}}$. Untuk membangkitkan data dengan metode SMOTE maka digunakan persamaan sebagai berikut:

$$
x_{\text {syn }}=x_{i}+\left(x_{k n n}-x_{i}\right) \gamma
$$

$\mathrm{x}_{\text {syn }}$ merupakan pengamatan baru hasil pembangkitan, $\mathrm{x}_{\mathrm{i}}$ adalah pengamatan $\mathrm{ke}-\mathrm{i}$, $\mathrm{xknn}$ merupakan $\mathrm{x}$ terdekat dari $\mathrm{x}_{\mathrm{i}}$, serta gamma merupakan bilangan acak antara 0 dan 1 . Untuk data nominal maka akan diisi dengan nilai mayoritas pada k-tetangga terdekat. Perhitungan jarak pada SMOTE apabila ada variabel kategorik maka akan diganti dengan kuadrat median standar deviasi variabel kontinyu kelas minoritas jika nilai kategorik pada pengamatan ke-i dan $\mathrm{j}$ berbeda.

\subsection{Pengukuran Hasil Prediksi}

Ukuran kinerja dari algoritma machine learning biasanya dievaluasi dengan confusion matrix seperti tampak pada gambar dibawah ini:

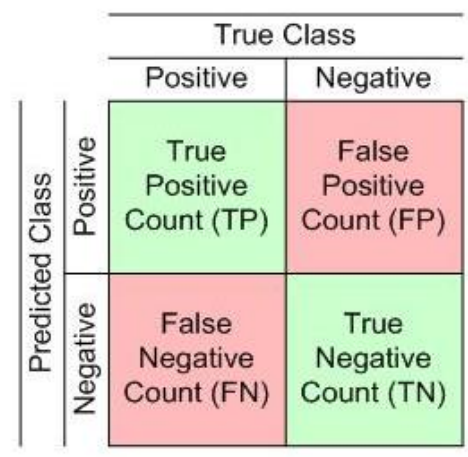

Gambar 1 Confusion Matrix Klasifikasi Biner

Nilai akurasi merupakan keakuratan prediksi secara keseluruhan sedangkan recall merupakan ukuran kebaikan model yang bisa digunakan untuk melihat keakuratan pada satu kelas terutama pada kasus dataset yang tidak seimbang. Nilai akurasi dan recall dapat dihitung dengan rumus sebagai berikut

$$
\text { Accuracy }=\frac{T P+T N}{T P+F P+T N+F N}, \text { recall }=\frac{T P}{T P+F N}
$$




\section{METODOLOGI PENELITIAN}

Data yang digunakan dalam penelitian ini adalah data sekunder, yaitu data pasien hepatitis C yang diperoleh dari UCI Machine Learning Repositery sebanyak 1385 data. Variabel data yang digunakan dalam penelitian ini adalah tingkat penyakit hepatitis $\mathrm{C}$ (fibrosis dan sirosis) sebagai variabel bebas dan terdapat 24 variabel bebas. Variabel bebas penelitian ini berupa data diri pasien, gejala, serta hasil uji laboratorium yaitu sebagai berikut: usia $\left(\mathrm{x}_{1}\right)$, jenis kelamin $\left(\mathrm{x}_{2}\right)$, indeks masa tubuh $\left(\mathrm{x}_{3}\right)$, demam $\left(\mathrm{x}_{4}\right)$, mual $\left(\mathrm{x}_{5}\right)$, sakit kepala $\left(\mathrm{x}_{6}\right)$, diare $\left(\mathrm{x}_{7}\right)$, rasa lelah $\left(\mathrm{x}_{8}\right)$, penyakit kuning $\left(\mathrm{x}_{9}\right)$, nyeri ulu hati $\left(\mathrm{x}_{10}\right)$, sel darah putih $\left(\mathrm{x}_{11}\right)$, sel darah merah $\left(\mathrm{x}_{12}\right)$, hemoglobin $\left(\mathrm{x}_{13}\right)$, trombosit $\left(\mathrm{x}_{14}\right)$, enzim AST week $1\left(\mathrm{x}_{15}\right)$, enzim ALT week 1 ( $\left.\mathrm{x}_{16}\right)$, ALT week 4 ( $\left.\mathrm{x}_{17}\right)$, ALT week $12\left(\mathrm{x}_{18}\right)$, ALT week $24\left(\mathrm{x}_{19}\right)$, ALT week $36\left(\mathrm{x}_{20}\right)$, ALT week $48\left(\mathrm{x}_{21}\right), \mathrm{HCV}$ RNA week $4\left(\mathrm{x}_{22}\right)$, HCV RNA week 12 ( $\left.\mathrm{x}_{23}\right)$, HCV RNA end of treatment $\left(\mathrm{x}_{24}\right)$. Variabel gejala bernilai kategorik biner dengan 0 berarti tidak mengalami gejala dan 1 berarti mengalami gejala.

Data dalam penelitian ini diolah dengan menggunakan python 3.7 dan $R$ studio. Langkahlangkah analisis dalam menyelesaikan penelitian ini adalah sebagai berikut:

1. Memasukkan data penelitian ke $\mathrm{R}$ studio untuk visualisasi data dan ke dalam python 3.7 untuk pemodelan secara lengkap

2. Melakukan pre-processing

a. Cek keberadaan missing value. Apabila data yang digunakan dalam penelitian terdapat missing value maka akan dilakukan imputasi menggunakan nilai rata-rata (variabel kontinyu) atau menggunakan nilai modus (variabel diskrit). Apabila tidak ada missing value maka akan dilanjutkan dengan deteksi outliers.

b. Deteksi outlier menggunakan boxplot. Apabila terdapat outlier pada data penelitian maka akan dihilangkan pengamatan yang mengandung outlier.

3. Melakukan copy dataset sehingga terdapat 2 dataset yang sama persis

- Dataset pertama tidak dilakukan balancing sehingga seperti data semula setelah preprocessing. Kemudian dilakukan langkah-langkah penelitian sebagai berikut:

a. Melakukan tuning hyperparameter random forest dan XGboost

b. Melakukan pembagian data train dan data test dengan holdout validation dan 5Fold cross validation

c. Membentuk model pohon klasifikasi random forest dan XGBoost

d. Melakukan prediksi untuk data train dan data test dengan model pohon klasifikasi random forest dan XGboost yang telah terbentuk

e. Melakukan pengukuran akurasi dan recall

- Dataset kedua dilakukan balancing sehingga jumlah data untuk kelas fibrosis dan sirosis sama. Balancing data dilakukan dengan algoritma SMOTE. Selanjutnya dilakukan langkah penelitian sebagai berikut:

a. Melakukan tuning hyperparameter SMOTE Random Forest dan SMOTE XGboost

b. Melakukan pembagian data train dan data test dengan holdout validation dan 5-Fold cross validation

c. Membentuk model pohon klasifikasi SMOTE random forest dan SMOTE XGBoost

d. Melakukan prediksi untuk data train dan data test dengan model pohon klasifikasi SMOTE random forest dan SMOTE XGboost yang telah terbentuk

e. Melakukan pengukuran akurasi dan recall

4. Menentukan model pohon keputusan terbaik diantara random forest, XGboost, SMOTE random forest, dan SMOTE XGboost berdasarkan nilai akurasi dan recall 


\section{ANALISIS DAN PEMBAHASAN}

\subsection{Pre-Processing}

Pengecekan adanya missing value dilakukan pada dataset awal. Setelah diamati maka dapat diketahui tidak ada data yang hilang kemudian dilanjutkan deteksi outlier dengan boxplot. Terdapat satu outlier pada kelas fibrosis pada variabel HCV RNA week 12. Outlier sangat jauh dari pengamatan lain dan hanya berjumlah satu sehingga dilakukan penghapusan observasi yang mengandung outlier sehingga data menjadi 1384 baris.

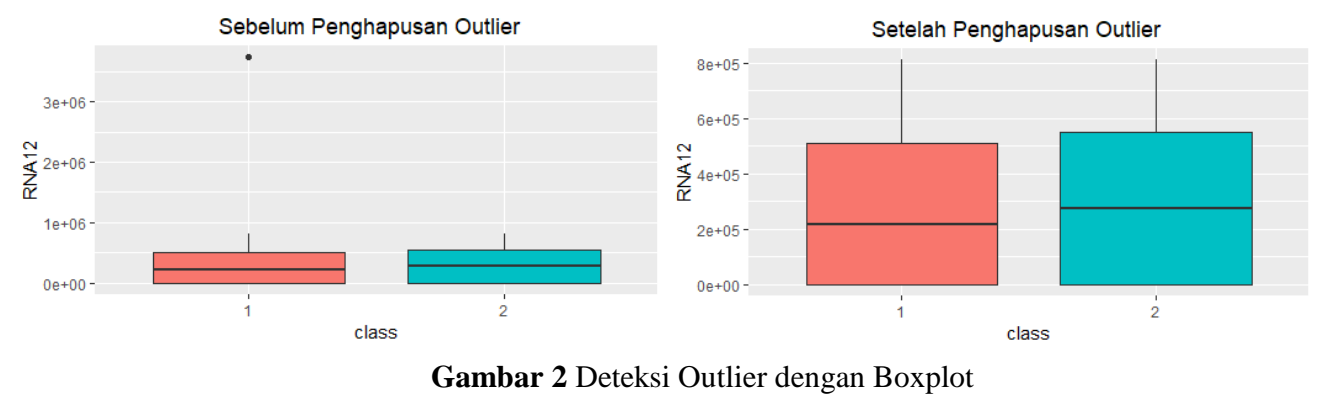

\subsection{Random Forest}

Penentuan parameter terbaik dari model dilakukan tuning secara simultan dengan grid search. Berikut ini adalah parameter yang dicobakan:

Tabel 1 Parameter Random Forest

\begin{tabular}{ll}
\hline Parameter & Nilai Parameter \\
\hline Mtry & $3,4,5,6,7,8,9,10,11,12$ \\
Ntree & $50,75,100,150,200,250$, \\
& $300,500,750,1000$ \\
\hline
\end{tabular}

Tuning parameter ini menggunakan 5-fold cross validation dan didapatkan parameter terbaik yaitu $m$ try $=3$ dan $n$ tree $=100$. Berikut ini adalah ukuran kebaikan model dari random forest .

Tabel 2 Ukuran Kebaikan Model Random Forest

\begin{tabular}{cccc}
\hline & Train-Test $(70 \%-30 \%)$ & Train-Test $(75 \%-25 \%)$ & Train-Test $(80 \%-20 \%)$ \\
\hline Akurasi & $75 \%$ & $75,72 \%$ & $73,65 \%$ \\
Recall & $0 \%$ & $0 \%$ & $0 \%$ \\
\hline
\end{tabular}

Tabel diatas menunjukkan nilai akurasi yang dihasilkan lebih dari $70 \%$ namun nilai recall yang dihasilkan bernilai 0\%. Nilai recall yang kecil mengindikasikan model tidak mampu memprediksi dengan benar pasien yang berada di tingkat sirosis. Pengembangan model yang dilakukan adalah dengan menambah algoritma SMOTE sehingga menjadi model SMOTE Random Forest.

\subsection{XGboost}

Penentuan parameter terbaik dari model dilakukan tuning secara simultan dengan random search 1000 percobaan. Berikut ini adalah parameter yang dicobakan: 
Tabel 3 Parameter XGboost

\begin{tabular}{ll}
\hline Parameter & Nilai Parameter \\
\hline Learning rate & $0.01,0.02,0.03,0.04,0.05$ \\
& $0.06,0.08,0.09,0.1,0.12$ \\
Max depth & $6,7,8,9$ \\
Min child weight & $0.7,0.8,0.9,1,1.2$ \\
Gamma & $0.1,0.2,0.3,0.4$ \\
Colsample by tree & $0.5,0.6,0.7,0.8$ \\
N estimators & $30,50,75,100,125$ \\
\hline
\end{tabular}

Tuning parameter ini menggunakan 5-fold cross validation dan didapatkan parameter terbaik yaitu min child weight $=0.7$, max depth $=7$, learning rate $=0.01$, gamma $=0.1$, colsample bytree $=0.5$, $n \_$estimators $=30$. Berikut ini adalah ukuran kebaikan model dari XGboost.

Tabel 4 Ukuran Kebaikan Model XGboost

\begin{tabular}{cccc}
\hline & Train-Test $(70 \%-30 \%)$ & Train-Test $(75 \%-25 \%)$ & Train-Test $(80 \%-20 \%)$ \\
\hline Akurasi & $75,24 \%$ & $75,14 \%$ & $73,65 \%$ \\
Recall & $1,94 \%$ & $0 \%$ & $0 \%$ \\
\hline
\end{tabular}

Tabel diatas menunjukkan nilai akurasi yang dihasilkan lebih dari $70 \%$ namun nilai recall yang dihasilkan kurang dari $2 \%$. Nilai recall yang kecil mengindikasikan model tidak mampu memprediksi dengan benar pasien yang berada di tingkat sirosis. Pengembangan model yang dilakukan adalah dengan menambah algoritma SMOTE sehingga menjadi model SMOTE XGboost.

\subsection{SMOTE Random Forest}

Penggunaan algoritma SMOTE membuat data dengan label sirosis menjadi lebih banyak dan jumlahnya sama dengan kelas fibrosis yaitu 1022 data.

Tabel 5 Jumlah Kelas Setelah Oversampling SMOTE

\begin{tabular}{ll}
\hline Tingkat Penyakit Hepatitis C & Jumlah Data \\
\hline Fibrosis & 1022 \\
Sirosis & 1022 \\
\hline
\end{tabular}

Setelah dilakukan balacing data maka dilakukan tuning parameter dengan parameter yang dicobakan sama dengan model random forest sebelumnya. Parameter terbaik untuk SMOTE random forest yaitu mtry $=3$ dan $n$ tree $=100$.

Tabel 6 Ukuran Kebaikan Model SMOTE Random Forest

\begin{tabular}{cccc}
\hline & Train-Test $(70 \%-30 \%)$ & Train-Test $(75 \%-25 \%)$ & Train-Test $(80 \%-20 \%)$ \\
\hline Akurasi & $79,64 \%$ & $81,60 \%$ & $81,66 \%$ \\
Recall & $72,89 \%$ & $78,16 \%$ & $75,59 \%$ \\
\hline
\end{tabular}


Tabel diatas menunjukkan ukuran kebaikan model dengan holdout validation. Nilai akurasi yang dihasilkan lebih dari $79 \%$ dan nilai recall yang dihasilkan lebih dari $72 \%$. Hasil rata-rata akurasi dan recall SMOTE random forest dengan spliting 5-fold CV berturut-turut yaitu sebesar $80,04 \%$ dan $75,34 \%$. Nilai recall yang tidak jauh berbeda dengan akurasi total mengindikasikan model telah mampu memprediksi dengan benar untuk kedua kelas.

Penentuan variabel yang lebih berpengaruh dalam pemodelan bisa menggunakan mean decrease gini (MDG). Nilai MDG dihitung dengan rata-rata gini sebuah variabel ketika variabel tersebut terpilih sebagai splitting node. Variable importance pada SMOTE random forest menunjukkan bahwa variabel dari uji laboratorium seperti jumlah trombosit dan enzim ALT lebih berpengaruh dibanding variabel data diri pasien maupun gejala.

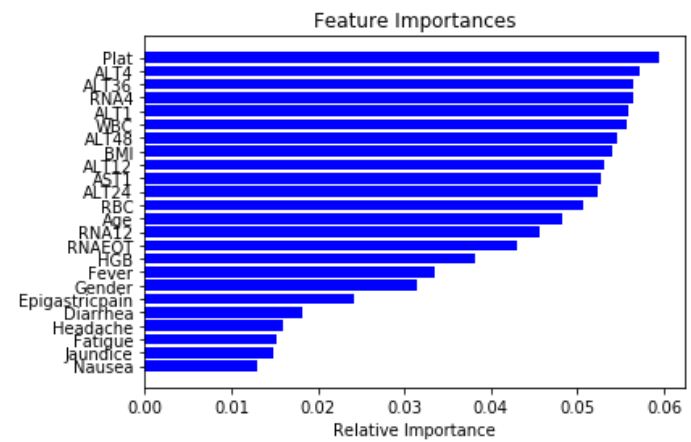

Gambar 3 Feature Importance SMOTE Random Forest

\subsection{SMOTE XGboost}

Penentuan parameter terbaik dari model dilakukan tuning secara simultan dengan random search 1000 percobaan. Berikut ini adalah parameter yang dicobakan:

Tabel 7 Parameter SMOTE XGboost

\begin{tabular}{ll}
\hline Parameter & Nilai Parameter \\
\hline Learning rate & $0.09,0.1,0.11,0.12,0.13$ \\
Max depth & $5,6,7,8$ \\
Min child weight & $0.6,0.7,0.8,0.9$ \\
Gamma & $0.1,0.2,0.3$ \\
Colsample by tree & $0.6,0.7,0.8$ \\
Nestimators & $50,75,100$ \\
\hline
\end{tabular}

Tuning parameter ini menggunakan 5-fold cross validation dan didapatkan parameter terbaik yaitu min child weight $=0.6$, max depth $=7$, learning rate $=0.1$, gamma $=0.2$, colsample bytree $=0.7, n \_$estimators $=100$

Tabel 8 Ukuran Kebaikan Model SMOTE XGboost

\begin{tabular}{cccc}
\hline & Train-Test $(70 \%-30 \%)$ & Train-Test $(75 \%-25 \%)$ & Train-Test $(80 \%-20 \%)$ \\
\hline Akurasi & $77,02 \%$ & $79,84 \%$ & $79,32 \%$ \\
Recall & $76,06 \%$ & $77,77 \%$ & $76,64 \%$ \\
\hline
\end{tabular}


Tabel diatas menunjukkan ukuran kebaikan model dengan holdout validation. Nilai akurasi yang dihasilkan lebih dari $77 \%$ dan nilai recall yang dihasilkan lebih dari $76 \%$. Hasil rata-rata akurasi dan recall SMOTE random forest dengan spliting 5-fold CV berturut-turut yaitu sebesar $78,72 \%$ dan $78,88 \%$. Nilai recall yang tidak jauh berbeda dengan akurasi total mengindikasikan model telah mampu memprediksi dengan benar untuk kedua kelas.

Penentuan variabel yang lebih berpengaruh dalam pemodelan bisa menggunakan frekuensi terpilihnya variabel tersebut sebagai pemilah, semakin besar frekuensi suatu variabel terpilih maka akan semakin besar pengaruhnya pada pemodelan. Variable importance pada SMOTE XGboost menunjukkan bahwa variabel dari uji laboratorium seperti jumlah sel darah merah dan jumlah HCV RNA lebih berpengaruh dibanding variabel data diri pasien maupun gejala.

\subsection{Perbandingan Metode Klasifikasi}

Nilai akurasi dari keempat metode yaitu random forest, XGboost, SMOTE random forest, dan SMOTE XGboost tidak jauh berbeda yaitu diatas 70\%, namun nilai recall antara model sebelum dan sesudah menggunakan SMOTE terlihat berbeda. Penggunaan SMOTE menyebabkan nilai recall random forest maupun XGboost yang dibawah $2 \%$ menjadi lebih dari $70 \%$.

Tabel 9 Perbandingan Akurasi dan Recall 4 Model

\begin{tabular}{ccccc}
\hline & Random Forest & XGboost & SMOTE RF & SMOTE XGB \\
\hline Akurasi & $74,79 \%$ & $74,68 \%$ & $80,97 \%$ & $78,63 \%$ \\
Recall & $0 \%$ & $0,65 \%$ & $75,55 \%$ & $76,82 \%$ \\
\hline
\end{tabular}

Gambar 4 menampilkan nilai akurasi (gambar kiri) dan recall (gambar kanan) data test pada model SMOTE random forest (merah) dan SMOTE XGboost (biru). Nilai akurasi dan recall data test tersebut berjumlah 500 untuk tiap metode yang dijalankan secara looping. Gambar paling kiri, tengah, dan kanan secara berurutan merupakan nilai akurasi serta recall data test pada proporsi split 70\%:30\%, 70\%:25\%, dan 80\%:20\%. SMOTE Random Forest cenderung memiliki akurasi yang lebih tinggi dibandingkan dengan SMOTE XGboost akan tetapi SMOTE XGboost memiliki nilai recall yang lebih tinggi dibandingkan SMOTE Random Forest.

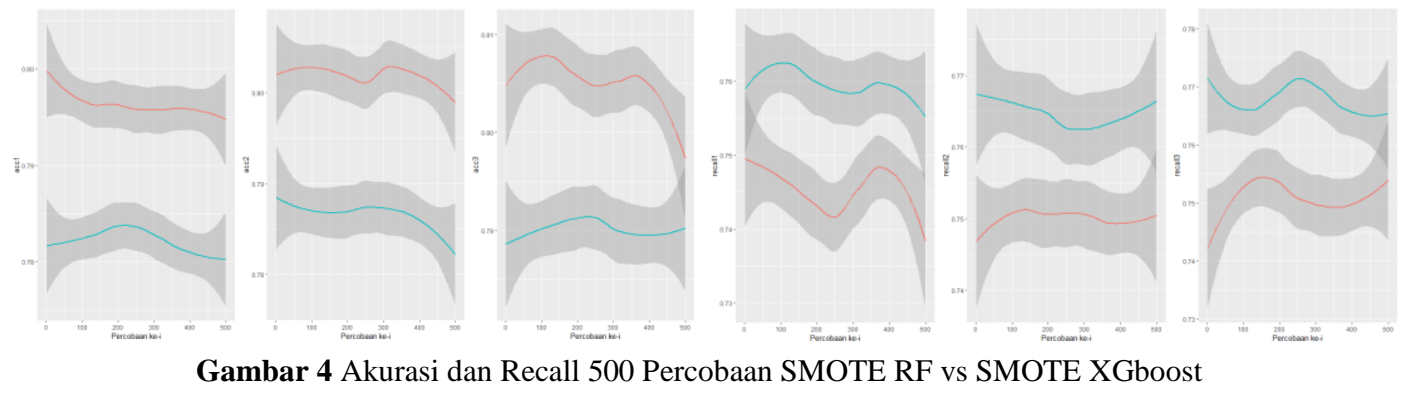

\section{KESIMPULAN}

Berdasarkan hasil pembahasan maka dapat diketahui bahwa algoritma SMOTE dapat memperbaiki model sehingga dapat memprediksi dengan akurat pada semua kelas respon. SMOTE Random Forest memiliki akurasi keseluruhan yang lebih tinggi dibanding SMOTE 
XGboost, namun XGboost memiliki recall kelas sirosis yang lebih baik. Variabel yang berpengaruh besar pada pemodelan SMOTE Random Forest dan SMOTE XGboost adalah variabel hasil uji laboratorium seperti jumlah sel darah, jumlah enzim ALT, serta jumlah HCV RNA dalam tubuh pasien.

\section{DAFTAR PUSTAKA}

[1] Barakat, N. H., Barakat, S. H., \& Ahmed, N., 2019. Prediction and Staging of Hepatic Fibrosis in Children with Hepatitis C Virus: A Machine Learning Approach. Healthcare Informatics Research, Volume 25,p. 173.

[2] Chawla, N.V., Bowyer, K. W., Hall, L. O. \& Kegelmeyer, W. P., 2002. SMOTE: Synthetic Minority Over-sampling Technique. Journal of Artificial Intelligence Research, Volume 16, p. 321-357

[3] Chen, T. \& Guestrin, C., 2016. XGBoost: A Scalable Tree Boosting System, Knowledge Discovery and Data Mining.

[4] Jajo, N. \& Matawie, K. M., 2019. Outlier Detection Using Boxplot. International Journal of Ecology and Development, Volume 13, pp. 116-122.

[5] John, T. M. S., 2008. Signs and Symptomps that May be Associated with Hepatitis C. Hepatitis C Choices. Caring Ambassadors Program, Inc., pp. 71-80

[6] Kotsiantis, S., Pintelas, P. E., \& Kanellopoulus, D., 2006. Data Preprocessing for Supervised Learning. International Journal of Computer Science, Volume 1, pp. 111-117.

[7] Raschka, S., 2018. Model Evaluation, Model Selection, and Algorithm Selection in Machine Learning.

[8] Sandt, L., 2008. Understanding Hepatitis C disease. Hepatitis C Choices. Caring Ambassadors Program, Inc., pp. 23-42.

[9] World Health Organization (WHO), 2019. Hepatitis C. Retrieved from https://www.who.int/news=room/fact-sheets/detail/hepatitis-c 